DOI: 10.46340/eppd.2021.8.1.16

Oleksandr Boyarskyy, PhD in Law, Judge of the Belgorod-Dniester City District Court of Odessa Region

ORCID ID: https://orcid.org/0000-0001-9107-4897

Legislation Institute of the Verkhovna Rada of Ukraine

\title{
A PERSON IN LOCAL GOVERNMENT: A CHOICE BETWEEN INDIVIDUAL AND COLLECTIVE EXISTENCE
}

\author{
Олександр Боярський, к. ю. н., суддя Білгород-Дністровського міськрайонного суду \\ Одеської області \\ Інститут законодавства Верховної Ради України
}

\section{ЛЮДИНА В МІСЦЕВОМУ САМОВРЯДУВАННІ: ВИБІР МІЖ ІНДИВІДУАЛЬНИМ ТА КОЛЕКТИВНИМ ІСНУВАННЯМ}

The purpose of this article is to study topical issues of human existence and functioning in local government in the context of his/her choice between individual and collective existence within the territorial community.

It is proved that the basis of the problem of the existence and functioning of a person in the conditions of local self-government within the territorial community has always been a very complex and contradictory factor of a person's social existence; there are corresponding existential attitudes of his/her individual existence in a local territorial community, connected with the fact that: a ) it is within the framework of the community that a person carries out his/her life cycle, starting from his/her birth and ending with his/her death (existential-temporal setting) b) such a life cycle is mainly carried out in the conditions of everyday life - a philosophical state when a person forms and uses typified forms of life - no wonder everyday life is understood as the sphere of habitual, monotonously repeated from day to day routine, small actions and deeds, understandable and accessible, performed almost automatically, without special tension of consciousness and reflection (everyday-simple installation); c) in the community, a person produces his/her existential intentions, aspirations, needs, interests, attitudes, which are then realized within its limits (motivational and stimulating sign); d) all the above existential attitudes are realized by a person through a system of communicative interaction with other members of the community in the form of appropriate rights and freedoms (communicative attitude); e) in local self-government conditions within the community, a person (individually or as part of a group, or collectively) consumes public goods of various properties (material, economic, political, spiritual, etc.) and uses the appropriate services, and they are provided by the community through the appropriate activities of local self-government bodies, which create the appropriate structure of the local economy (local civilizational setting).

It is argued that for a deeper study of the problems of the existence and functioning of a person in conditions of local self-government, we consider it necessary to build an appropriate system of coordinates "person - local self-government", based on the main, indicative features, which in their development demonstrate the parametric limits of the profile system, namely, provide an opportunity, define and highlight the following positions: a) a person as an individual within the local community and in conditions of self-organization (within local government); b) a person as a central figure-subject of local self-government (human-centrism in local self-government) c) a person in local self-government as in the implementation of his/her life cycle; d) a person in the sphere of manifestation of his/her needs and interests; e) a person in the field of socialization, including legal socialization; f) a person in the sphere of manifestation of his/her rights, freedoms 
and fulfillment of duties; $f$ ) a person in the sphere of manifestation of public power at the local level of society.

It has been established that the above positions (signs) are in a system-complex logical existentialactivity mutual connection with each other, since they are connected through spatial (social space) and interpersonal (communicative interaction) connections, principles, concepts and socioindividual, social-group and social-collective attitudes, teleological dominants and practical results of human functioning in local self-government.

It is proved that the system analysis of the above positions (features) convincingly proves the advantages of the collective existence of a person within the territorial community in the context of local self-government in order to realize his/her existential needs and interests.

Keywords: person, human rights, local government, territorial community, person in local selfgovernment.

Постановка проблеми. Проблематика існування і функціонування людини в умовах місцевого самоврядування (далі - МСВ) в межах територіальної громади (далі - ТГ) завжди представляла собою вельми складний та суперечливий фактор соціального буття людини, який досить активно досліджувалася системним комплексом наук, починаючи з філософії, і закінчуючи соціологією, політологією та юриспруденцією.

Причиною такого стану справ 3'явились відповідні екзистенційні настанови людського індивідуального існування в локальній територіальній спільноті, що пов'язані 3 тим, що: а) саме в рамках ТГ людина здійснює свій життєвий цикл, починаючи його від свого народження, i закінчуючи ії смертю (екзистенційно-темпоральна настанова. - Авт.); б) такий життєвий цикл переважно здійснюється в умовах повсякденності - філософського стану коли людина формує і використовує типізовані форми життєдіяльності- недарма повсякденність розуміли як сферу рутинних, звичних, одноманітно повторюваних здня у день малих дій і вчинків, зрозумілих i доступних, виконуваних майже автоматично, без спеціального напруження свідомості і рефлексії ${ }^{1}$ (повсякденно-ординарна настанова. - Авт.); в) саме в ТГ людина продукує свої екзистенційні інтенції, устремління, потреби, інтереси, атитюди, які потім реалізуються в ії межах (мотиваційностимулююча ознака. - Авт.); г) всі наведені екзистенційні настанови реалізуються людиною через систему комунікативної взаємодії з іншими членами ТГ у вигляді відповідних прав і свобод (комунікативна настанова. - Авт.); г') саме в умовах МСВ в межах ТГ людина індивідуально, або в складі групи, або колективно потребляє суспільні блага різної властивості (матеріальні, економічні, політичні, духовні тощо) та користується відповідними послугами, що їй надає ТГ через відповідну діяльність органів місцевого самоврядування (далі - ОМСВ), які створюють відповідну структуру місцевого господарства (локально-цивілізаиійна настанова. - Авт.).

Отже, саме наведені настанови об'єктивують, актуалізують та контекстуалізують проблематику людини в місцевому самоврядування та детермінують ії вибір між індивідуальним та колективним існуванням.

Аналіз останніх досліджень і публікацій. Треба зазначити, що проблематика людини в місцевому самоврядуванні у вітчизняній правовій науці практично не досліджувалась. Основні зусилля вчених зосереджувались на питаннях правової природи МСВ, його подальшої легалізації і легітимації в умовах демократичної правової державності, становлення компетенції ОМСВ і набуття ТГ належної правосуб'єктності. Дослідженню людського виміру МСВ, правового статусу людинижителя-члена ТГ, особливо в контекстуалізації його участі в МСВ і становленні муніципалізму, присвячені праці багатьох українських та іноземних учених, а саме: М. О. Баймуратова, О. В. Батанова, В. І. Васильєва, А. В. Левенець, О. Г. Лиски, М. П. Орзіх, С. А. Панасюка, В. Ф. Погорілка, О. Ф. Фрицького, М. Ф. Малікова, А. І. Черкасова, Є. І. Колюшина та ін. Однак дослідженню питань визначення системи координат «людина - місцеве самоврядування», - особливо в акцентуації вибору між індивідуальним іiї існуванням та колективним функціонуванням в рамках громади умовах демократичної правової державності, що відповідають сучасним тенденціям розвитку муніципального права, увага практично не приділялась.

\footnotetext{
${ }^{1}$ Коляструк, О. (2009). Поняття повсякденності в сучасній науковій гуманітаристиці. Україна XX cm.: культура, ідеологія, політика, 15, 46. <http://resource.history.org.ua/publ/xxx_2009_15_1_46> (2021, січень, 26).
} 
Тому метою цієї статті $\epsilon$ дослідження актуальних питань існування і функціонування людини в місцевому самоврядуванні в контекстуалізації іiі вибору між індивідуальним та колективним існуванням в межах ТГ.

Викладення основного матеріалу. Для дослідження проблематики статті, що торкається досить складних аспектів взаємовідносин людини та їі асоціацій на рівні груп та колективів, що формуються, існують, функціонують, розвиваються на рівні локального соціуму в царині «інтересів», репрезентуючи їх на різних рівнях існування ТГ (мікрорівень /людина; iї родина; іiі «близьке комунікативне коло» тощо/, мезорівень /трудовий колектив; колектив учнів, студентів; групи людей, що об'єднуються на основі національних, етнічних, культурологічних, наукових, спортивних та ін. інтересів тощо/, макрорівень /рівень самої ТГ/) та реалізуючи в умовах повсякденності у реальному житті, вважаємо за потрібне зробити декілька зауважень методологічної властивості, що будуть сприяти побудові відповідної системи координат в якій знаходиться людина, функціонуючи в умовах МСВ.

Отже, вважаємо за потрібне зробити акцент на існування в наведеній системі координат «людина - MCВ» основоположних, на нашу думку, індикативних ознак, що в своєму розвитку демонструють параметральні межі профільної системи. Виходячи з такого підходу, треба визначити та виокремити наступні позиції:

-людина як індивідуум в рамках локальної спільноти та в умовах самоорганізації (в межах $\mathrm{MCB})$;

- людина як центральна фігура-суб'єкт МСВ (людиноцентризм в МСВ);

- людина в МСВ як в сфері реалізації свого життєвого циклу;

- людина в сфері прояву своїх потреб і інтересів;

- людина в сфері соціалізації, в тому числі і правової соціалізації;

- людина в сфері прояву своїх прав, свобод і виконання обов'язків;

- людина в сфері прояву публічної влади на локальному рівні соціуму.

Треба зазначити, що наведені ознаки знаходяться одна з одною у системно-комплексному логічному екзистенційно-діяльнісному взаємному зв'язку, так як є пов'язаними через просторові (соціальний простір) та міжособистісні (комунікативна взаємодія) зв'язки, засади, концепти та соціально-індивідуальні, соціально-групові і соціально-колективні настанови, телеологічні домінанти та практичні результати. По великому рахунку, тут необхідно погодитись з позицією М.П. Орзіх, відповідно до якої, по-перше, в сучасному конституційному праві «людина» стає не тільки основною категорією конституційного права (в нашому випадку і муніципального права. - Авт.), але є головним ціннісним орієнтиром його розвитку, індикатором перевірки на реалізація конституційних правоположень, теорій, ідей, інститутів, конституційної практики ${ }^{1}$, i, по-друге, враховуючи наступне, саме в системі координат «людина - МСВ» проходять інтенсивні процеси становлення і сталого функціонування системозберігального механізму, представленого презумпціями, прецедентами, фікціями, преюдиціями, способами подолання і заповнення прогалин у законі, колізійними угодами, меморандумами, деклараціями, звичаями (звичаєвостями), традиціями, міжнародно-правовими стандартами ${ }^{2}$.

I хоча останнє зауваження наведеного автора торкаються визначення системоутворювальної функції конституції, конституційного законодавства і права, конституційної практики щодо правової системи країни,- вони є вельми слушними і для характеристики системоутворюючих процесів в сфері МСВ, особливо в процесі:

а) визначення та визнання статусу людини в межах локальної демократії, коли безліч форм локального життя, що набувають для людини, ii груп і асоціацій екзистенційного значення, об'єктивно викликають до життя необхідність їх організаційного та організаційно-правового супроводження і забезпечення;

б) реалізації в межах МСВ конституційно-правового статусу людини (особистості)

в) прояву багатофакторних та багаторівневих інтенцій, устремлінь, потреб, інтересів, атитюдів людини, що носять типізований характер і об'єктивно спонукають законодавця використовувати широкий арсенал юридико-організаційних та юридико-процесуальних інститутів, засобів, правил (презумпції, прецеденти, фікції, преюдиції, способи подолання і заповнення прогалин у законі

\footnotetext{
${ }_{1}^{1}$ Орзих, М. Ф. (2015). Опьт введения в конституциионное право Украиныл. Одеса: Юридична література, 325.

2 Там само, 316.

${ }^{3}$ Кофман, Б. Я. (2019). Муніципальні права людини (особистості) як фактор вдосконалення конституційноправового статусу людини і громадянина. Часопис Киїського університету права, 2, 70.
} 
/аналогія права і аналогія закону/, колізійні угоди, меморандуми, декларації, звичаї (звичаєвості), традиції, міжнародно-правові стандарти тощо) для супроводження i забезпечення їх наступної реалізації в межах локальної людської спільноти.

Розглянемо наведені вище позиції більш детально, з метою демонстрації загальної соціальнонормативної картини буття людини в сфері МСВ:

1. Людина як індивідуум в рамках локальної спільноти та в умовах самоорганізачії (в межах $M C B$ ).

Основоположними настановами цієї позиції, на наш погляд, є наступні положення, що, безумовно, володіють методологічною властивістю:

-людина приречена народитися, існувати, розвиватися як особистість і жити в межах територіальної людської спільноти - ТГ;

- саме в межах ТГ в умовах МСВ людина здійснює свій життєвий цикл;

- здійснення людиною свого життєвого циклу в межах ТГ об'єктивує і детермінує виникнення, формування, прояв і реалізацію нею своїх індивідуальних інтенцій, устремлінь, потреб, інтересів, атитюдів, що мають екзистенційний характер, - тобто $\epsilon$ пов'язаними з задоволеннями іiі життєвоважливих настанов іiі біологічного, соціального, економічного і культурологічного існування;

-отже, виникнення, формування, прояв і реалізація наведених екзистенційних настанов здійснюється людиною в умовах МCB, що трансформує останнє в природну і оптимальну сферу їх існування та виконання;

- але, враховуючи на колективний характер MCB, що апріорі здійснюється територіальною людською спільнотою - ТГ, людина об'єктивно повинна, щоб уникнути їх нівелювання або нейтралізацію: a) співвідносити свої індивідуальні екзистенційні настанови з загальними колективними екзистенційними настановами, що продукує ТГ; б) пристосовувати свої індивідуальні екзистенційні настанови до таких загальних колективних екзистенційних настанов, що продукує ТГ; в) трансформувати свої індивідуальні екзистенційні настанови до загальних колективних екзистенційних настанов, що продукують ТГ, на принципах синергії за допомогою системи комунікативної взаємодії;

-звідси, індивідуальні екзистенційні настанови людини, що формуються в умовах повсякденності, мають типізований характер,- причому вони можуть бути реалізованими нею в межах ТГ тільки в умовах їх безконфліктності з загальними колективними екзистенційними настановами, що продукують ТГ, за рахунок комунікативної взаємодії з іншими членами ТГ, що забезпечує превенцію колізій і зняття «конфлікту інтересів»;

-отже, знаходячись в рамках локальної спільноти, людина як індивідуум в умовах самоорганізації (в межах МСB), може реалізувати свої індивідуальні екзистенційні настанови буття тільки завдяки їх співвіднесенню та упорядкуванню (координації) з загальними колективними екзистенційними настановами, що продукують ТГ, за рахунок комунікативної взаємодії, причому, остання виступає сферою зняття протиріч, що можуть виникнути в цьому процесі. Отже, саме таким чином детермінується фактор інтерсуб'єктивності, як риси конкретної людини, що означає ії устремління існувати та функціонувати в межах територіальної спільноти людей задля реалізації своїх внутрішніх екзистенційно-ціннісних настанов. Наведений фактор носить інтегративно-системний характер, бо, по-перше, означає особливу спільність (формування і наявність фактору співпричетності. - Авт.); по-друге, ідентифікує певну сукупність людей, що володіють спільністю установок і поглядів (формування і наявність фактору екзистенційних настанов. - Авт.); по-третє, демонструє наявність узагальненого досвіду уявлення предметів оточуючого середовища ${ }^{1}$ (формування і наявність фактору природно-соціального досвіду. - Авт.). Крім того, необхідно враховувати, що проблема інтерсуб'єктивності виникає як спроба відповісти на питання, як індивідуальна свідомість виходить до досвіду іншого «Я» i через це до універсального горизонту досвіду ${ }^{2}$. Отже, саме так, через спробу пізнання і процес пізнання іншого, людина входить до соціальної спільноти, починає в ній існувати і функціонувати, обираючи саме такий локальний простір як найбільш оптимальний та продуктивний для своєї життєдіяльності. Звідси, можна стверджувати, що саме в межах ТГ, в умовах МСВ, що запускає

\footnotetext{
${ }^{1}$ Википедия. Свободная энциклопедия (2021). Интерсубъективность

$<$ https://ru.wikipedia.org/wiki/Интерсубъективность> (2021, січень, 26).

${ }^{2}$ Новая философская энциклопедия (2021). Интерсубъективность

$<$ https:/iphlib.ru/library/collection/newphilenc/document/HASH44342313953cffcc43a844> (2021, січень, 26).
} 
могутні процеси самоорганізації людина як соціальна істота здійснює процес конституювання у свідомого суб'єкта локального соціуму.

2. Людина як иеентральна фігура-суб'єкт МСВ (людиноцентризм в МСВ).

Основоположними настановами цієї позиції, на наш погляд, $є$ наступні положення, що, безумовно, володіють методологічною і технологічною властивістю:

-людина виступає центральним суб'єктом-об'єктом сучасного конституційного права, як єдиної фундаментальної та профілюючої галузі національного права і національного законодавства ${ }^{1}$, а також муніципального права, що $€$ новою галуззю національного права i національного законодавства ${ }^{2}$, бо основоположні правовідносини, що виникають між людиною, соціумом i державою «обертаються» навколо людини, іiї інтересів та нормативних настанов ії поведінки;

- такий підхід щодо людиноцентризму в праві підтверджується особливим інституційним значенням конституційних прав і свобод людини і громадянина для становлення, розвитку i вдосконалення демократичної правової державності, а також для функціонування міжнародної спільноти держав, - саме в умовах глобалізації права і свободи людини (особистості) становлять не тільки основоположну ідентифікаційну ознаку демократичної держави, а і виступають основним об'єктом міжнародного міждержавного співробітництва ${ }^{3}$;

-в основі людиноцентричності в праві лежить той нормативно-технологічний фактор, що основний зміст багатьох юридичних гарантій свободи людини (особистості) полягає в забезпеченні необхідних умов для нормального життя, активної діяльності громадян в суспільстві, що на практиці здійснюється на локальному рівні функціонування соціуму в межах ТГ та в умовах МCB;

-генетичні засади людиноцентричності в праві містяться в тому, що природні права і свободи людини фактично не створюються державою, а, отже, і не можуть бути нею обмежені, - такі права: a) $є$ проявом природи людини; б) виникають в історичній ретроспективі завдяки багатовіковому функціонуванню людської істоти в межах територіальної людської спільноти - ТГ; в) базується на соціальній практиці; г) виникають завдяки спільному проживанню; г’) формуються завдяки наявності загальних телеологічних домінант існування, співіснування та життєдіяльності; д) володіють екзистенційною властивістю;

-місце і роль ідеології людиноцентризму в конституційно-правовій доктрині України та сучасному конституційному процесі детерміновані тим, що сам принцип людиноцентризму повинен пронизувати всі зміни Основного Закону, включаючи розширення і поглиблення форм участі громадян в управлінні державою, підвищення ролі виборів i референдумів, становлення громадянського суспільства, вдосконалення місцевого самоврядування, реформування судової системи і т. п. ${ }^{4},-$ причому, слід зазначити, що всі наведені діяльнісно-функціональні характеристики профільного принципу на практиці здійснюються переважно або тільки в умовах МСВ, в межах ТГ та в ординарних настановах функціонування державності;

- великого значення з огляду на це, набуває вивчення європейської практики реалізації прав, свобод і законних інтересів людини, яка для України, як держави-підписанта і учасника Європейської конвенції з захисту прав людини і основоположних свобод 1950 року, набуває особливого i обов'язкового характеру - насамперед, по-перше, реалізація таких прав і свобод, а також законних інтересів людини здійснюється на локальному рівні функціонування соціуму в межах ТГ, в умовах $\mathrm{MCB}$, a, по-друге, в процесі цього спостерігається поглиблення приватноправових основ в правовому регулюванні суспільних відносин на рівні ТГ і МСВ, як прояву природи людиноцентризму;

- наявність закріплення принципу людиноцентризму на міжнародному рівні, - у Рекомендації Конгресу місцевих і регіональних влад Свропи 280 (2010) про роль місцевих і регіональних органів влади в дотриманні прав людини (переглянута) від 19 жовтня 2011 р. ${ }^{5}$ зазначається, що демократія

\footnotetext{
${ }^{1}$ Орзих, М. Ф. (2015). Конституичия - системообразующая основа права Украины: прикладные проблемыл. Одеса: Юридична література, 345-346.

${ }^{2}$ Галіахметов, І. А. (2016). Муніципальне право Украӥни: методологія становлення та розвитку. Київ: КНЕУ, 95. ${ }^{3}$ Кофман, Б. Я. (2020). Роль міжнародних правових стандартів прав людини у формуванні правового статусу людини і громадянина. Часопис Київського університету права, 1, 111-112.

${ }^{4}$ Голос Украины (2017). Человекочентризм: контекст научных реалий $<$ http://www.golos.com.ua/rus/article/289180> (2021, січень, 26).

${ }^{5}$ Рекомендації Конгресу місиевих і регіональних влад Європи 280 (2010) про роль місиевих і регіональних органів влади в дотриманні прав людини, 2011 (Рада Свропи). Council of Europe <https://rm.coe.int/168071b6bc > (2021, січень, 26).
} 
і права людини є взаємозалежними, причому демократія, зокрема на місцевому та регіональному рівнях, не може існувати без безумовного дотримання прав людини. У цьому ж документі фактично закріплена парадигма реалізації людиноцентризму на рівні МСВ за рахунок здійснення державамичленами Ради Європи, а також їх органами МСВ на регіональному і місцевому рівнях відповідних дій організаційного і організаційно-правового характеру відповідної телеологічної спрямованості, а саме:

А) місцеві і регіональні органи влади повинні виконувати ті обов'язки, пов'язані з правами людини, які випливають із міжнародних зобов'язань держав-членів, при цьому лише в межах своїх місцевих/регіональних повноважень (облігаторний критерій. - Авт.);

Б) місцеві та регіональні органи влади $є$ не тільки представниками центрального уряду - вони забезпечують права людини одночасно з тим, як вони здійснюють МСВ (предметно-забезпечуючий критерій. - Авт.);

В) ефективне управління є таким управлінням, яке засноване на дотриманні прав, при цьому виконання обов'язків, пов'язаних із правами людини, $\epsilon$ тим викликом, подолання якого може зміцнити демократію на місцевому рівні (гуманістично-управлінський критерій. - Авт.);

Г) необхідно забезпечувати, щоб місцевим і регіональним органам влади виділялися такі фінансові ресурси, рівень яких дасть змогу цим органам влади належним чином дотримуватися прав людини і при цьому розглядати й розвивати свою власну діяльність для дотримання цих прав (належно-ресурсний критерій. - Авт.);

Г') необхідно залучати представників місцевих і регіональних органів влади до підготовки національних стратегій, політики та індикаторів у галузі прав людини для того, щоб використовувати їхній внесок і прагнути усвідомлення ними відповідальності щодо дотримання прав людини (інтеграційно-проєктний критерій. - Авт.);

Д) необхідно заохочувати місцеві і регіональні органи влади до того, щоб сприяти дотриманню прав людини через ініціативи просвітницького характеру, а також завдяки здійсненню місцевих і регіональних планів дій (проспективно-просвітницький критерій. - Авт.);

Е) необхідно сприяти створенню незалежних механізмів розгляду скарг на місцевому та регіональному рівнях, i, зокрема, створювати незалежні органи, такі як місцеві чи регіональні омбудсмени або уповноважені, здатні знайти відповіді в тих випадках, коли права людини повною мірою не дотримуються, зокрема, при наданні публічних послуг на місцевому рівні тощо (правозахисний критерій. - Авт.);

€) у цих Рекомендаціях Конгрес особливо наголошує, що найважливіше значення для поліпшення становища в галузі прав людини в Свропі на всіх рівнях має освіта і прийняття відповідних стандартів (нормотворчо-стандартизований критерій. - Авт.);

-треба погодитись з продуктивною позицією О.В. Батанова, відносно того, що стрімкий розвиток муніципального права у сучасних демократіях, тріумфальний рух принципів субсидіарності, регіоналізації та децентралізації, який відбувся у період після Другої світової війни в Свропі та США, породив тенденцію муніципалізації конституційного життя зокрема та правових систем загалом свідченням цього є становлення системи муніципальних прав людини, механізмів їх гарантування і захисту, що є основою для соціального гомеостазу ТГ, який, з одного боку, $\epsilon$ невід'ємною характеристикою організації та діяльності МСВ на певній території та, з другого боку, властивістю сучасного муніципального права, яке, зі свого боку, виконує специфічну гомеостазисну роль у процесах формування соціально-правової державності та громадянського суспільства ${ }^{1}$. Отже, з наведеної доктринальної позиції можна зробити висновки, що:

а) в основі людиноцентричності МСВ лежить тенденція муніципалізації конституційного життя (тенденція предметно-якісної трансформації. - Авт.);

б) вона сформувалась завдяки стрімкому розвитку муніципального права у сучасних демократіях, що базується на принципах субсидіарності, регіоналізації та децентралізації (тенденція розвитку засадничих підходів. - Авт.);

в) ії ярким проявом виступає становлення системи муніципальних прав людини та механізмів їх гарантування і захисту (тенденція появи якісно нового виду прав людини. - Авт.);

г) саме муніципальні права людини $\epsilon$ основою для соціального гомеостазу (самозбереження та самовідтворення завдяки системі внутрішньої самостабільності. - Авт.) ТГ (тенденція появи якісно нової соціальної системи гомеостазу. - Авт.);

\footnotetext{
${ }^{1}$ Батанов, О. В. (2017). Людиноцентризм у муніципальному праві: теоретичні та прикладні аспекти. Альманах права, 8, 69.
} 
г’) такий гомеостаз є невід’ємною характеристикою організації та діяльності МСВ на певній території (тенденція появи, функціонування, існування і структурування якісно нової соціальної системи гомеостазу. - Авт.);

д) він також виступає властивістю сучасного муніципального права, яке, своєю чергою, виконує специфічну гомеостазисну роль у процесах формування соціально-правової державності та громадянського суспільства (тенденція появи системи гомеостазу в новій галузі національного права і національного законодавства. - Авт.);

е) органічне поєднання соціального і нормативного гомеостазу в муніципальному праві 3 тенденціями самоорганізації, що $\epsilon$ стратегічними у $\mathrm{MCB}$, не тільки підсилює фактор інтерсуб'єктивності, а і формує його як основоположний і визначальний ускладних процесах конституювання ТГ, людини-жителя як члена такої громади та МСВ як особливого соціальнонормативного простору, що виникає і функціонує в умовах демократичної правової державності;

є) співвідносячи наведене, відносно людини в системі МСВ можна зазначити ії основоположну роль в досягненні, дотримання і збереженні гомеостазу ТГ та всієї системи МСВ, бо всі наведені інститути базуються саме на людині та іiї інтересах, що втілюються у відповідних іiі правах і свободах в рамках ТГ, які базуються на стійких поведінково-діяльнісних патернах (тенденція появи основоположного суб'єкту-об'єкту гомеостатичного впливу і результату в рамках МСВ. - Авт.);

3. Людина в МСВ як в сфрері реалізаиії свого життєвого изиклу.

Основоположними настановами цієї позиції, на наш погляд, $є$ наступні положення, що, безумовно, володіють методологічною, біосоціальною та технологічною властивістю, а саме:

- вперше поняття «життєвий шлях особистості» було запропоновано психологом Шарлотта Бюлер у 1928 р., - згідно з ії теорією, життя складається з внутрішніх і зовнішніх подій. А головна мотивація особистості - прагнення до самореалізації, пошук та знайти себе у творчості. Отже, життя проходить за трьома лініями: 1) лінія об'єктивної логіки, тобто низки зовнішніх подій (зовнішньоспостережливий фактор. - Авт.); 2) лінія суб'єктивної логіки, тобто низки переживань, пов'язаних 3 цими подіями (внутрішньо-емоційний фактор. - Авт.); 3) лінія результатів діяльності ${ }^{1}$ (прагматично-результативний фактор. - Авт.). Отже, цей феномен необхідно розуміти як:

a) системний і комплексний, бо здійснюється на протязі всього життя людини в межах ТГ на локальному рівні існування і функціонування соціуму;

б) заснований на логічно-чуттєвих (раціонально-абстрактних) засадах від сприйняття оточуючого соціального середовища в рамках існування і функціонування локальної людської спільноти в умовах МСB;

в) такий, що базується на внутрішньо поставлених телеологічних домінантах в функціональнодіяльнісній поведінці людини, що збігаються з настановами ії індивідуальної, індивідуальногрупової, індивідуально-колективної комунікативної взаємодії у середині ТГ в умовах МСВ;

г) такий, що має суб'єктну (конкретна людина-член локального соціуму) та темпоральну (впродовж всього життя конкретної людини-члена ТГ) характеристики;

г') володіє відповідною подієво-діяльнісною характеристикою (шлях /цикл/ реалізується через відповідну поведінку людини завдяки здійсненню відповідних усвідомлених або неусвідомлених дій при виконанні рольових позицій в соціумі, що існує в умовах МСВ в межах ТГ в процесі комунікативної взаємодії з іншими членами локального соціуму);

д) характеризується відповідною результативністю та наявністю логічного причинного зв'язку між нею та попередніми телеологічно-діяльнісними настановами людини, а також досягненням нею відповідних телеологічних домінант (виконання відповідних рольових позицій в соціумі, досягнення нових рольових позицій, завдяки соціалізації, причому, як завдяки активній /соціальний ріст, кар'єра, освіта, матеріальний достаток тощо/, так і завдяки пасивній /досягнення відповідного віку/ формам поведінки);

- слідом за Бюлер французький психолог П'єр Жане також став вивчати цей феномен, - згідно з ним, життєвий шлях особистості в психології- це еволюція особистості, низка вікових етапів розвитку, етапів біографії르. Тобто, фактично мова йде про життя конкретної людини, що проходить в локальному соціумі увідповідний темпоральний період та характеризується відповідними

\footnotetext{
${ }^{1}$ Путешествия и фото (2020). Что такое жизненный путь и как определить приоритеть в жизни? $<$ https://cutt.ly/nkXmM3Z> (2021, січень, 26).

${ }^{2}$ Максименко, С. Д. (2021). Загальна психологія, 96. Westudents.com.ua $<$ https://westudents.com.ua/glavy/76983jittviy-shlyah-lyudini. html> (2021, січень, 26).
} 
досягненнями та упущеннями, успіхами та поразками, позитивом та негативом, - саме таке повсякденне життя і є пов'язаним з комунікацією всередині ТГ, МСВ, станом повсякденності, що дають можливість людині (особистості) самоідентифікуватися, досягнути розуміння та самостійно інтерпретувати власний життєвий досвід, набутий нею впродовж життя, у процесах проєктування і прогнозування власного майбутнього. Більш того, це дає людині можливість співвіднести набутий життєвий досвід та усвідомити власні життєві перспективи ${ }^{1}$. Отже, саме звідси й випливає важлива стратегічна роль ТГ, як колективного суб'єкта в рамках якого формується і здійснюється комунікативна взаємодія; МСВ як сфери існування і функціонування ТГ та окремих їі членів у різних рольових позиціях в рамках такої комунікативної взаємодії; та стану повсякденності, що стимулює та детермінує життєвий шлях (цикл) людини та виступає важливою передумовою іï соціалізації та наступного розвитку;

- на думку представників психологічної науки, життєвий цикл людини - це окремі, повторювані інтервали їі розвитку. Прийнято виділяти такі цикли: біологічні (онтогенез), соціальні (соціалізація, адаптація), біосоціальні (зміна соціальних ролей разом з етапами дорослішання, тобто зміни поколінь $)^{2},-$ визначаючи глобальну роль конституційного права в соціальному регулюванні найважливіших відносин між людиною, соціумом $\mathrm{i}$ державою, а також стратегічну роль муніципального права у регулюванні повсякденних відносин між конкретною людиною і ТГ, що існує i функціонує в стані повсякденності в умовах МСВ, для нас представляє важливість всі наведені цикли загального життєвого циклу людини, бо саме завдяки ним, за їх допомогою або безпосередньо через них людина продукує свої інтенції, устремління, потреби, інтереси, атитюди, формує патерни, що трансформуються у їі конституційні права і свободи, що проявляються у вигляді муніципальних прав людини (особистості, члена ТГ) ${ }^{3}$. Так, біологічні цикли (онтогенез) формують вітально-екзистенційні права і свободи людини; соціальні цикли (соціалізація, адаптація) напряму сприяють формуванню соціального буття людини, їі габітусу через усвідомлення, набуття і реалізацію саме нею системного комплексу економічних, соціальних, культурних, екологічних та інших прав і свобод; біосоціальні цикли (зміна соціальних ролей разом з етапами дорослішання, тобто зміни поколінь) детермінують виникнення, формування, існування, функціонування i реалізацію системного комплексу всіх видів прав і свобод людини (особистості), включаючи i політичні права (права і свободи громадянина), що дає можливість людини вільно орієнтуватися у соціально-правовому просторі держави, що репрезентований локальним соціальним простором, відображає загальний соціально-правовий простір та стимулює локальний простір до існування, функціонування, розвитку і вдосконалення.

- особливе значення у визначенні ролі МСВ як сфери, де здійснюється життєвий цикл людини, має системний і комплексний характер усвідомлення і розуміння цього феномену. Так, відомий радянський вчений-психолог С.Л. Рубінштейн, що зробив суттєвий внесок у вивчення профільної феноменології, вважав, що життєвий шлях - це не просто розвиток організму, а додавання людиною своєї історії. Отже, шлях відображає сутність особистості. На думку Рубінштейна, тільки того, у кого $\epsilon$ своя історію, можна назвати особистістю. Більш того, лінія, що веде від того, чим людина була на одному етапі своєї історії, до того, ким вона стала на наступному, проходить через те, що вона зробила. Звідси, життєвий шлях людини складається 3 подій - конфліктні моменти (переломні моменти), вирішення яких в загальних рисах визначає найближче майбутнє особистості ${ }^{4}$. Враховуючи на наведені вище локальні, темпоральні, суб'єктно-об'єктні характеристики феномену життєвого циклу, що мають стратегічний характер для його осмислення і розуміння, треба звернути увагу на його полісемічний характер, бо в науці він розуміється як сукупність, системокомплекс трьох понять - життєвого шляху, часу життя, життєвого циклу.

\footnotetext{
${ }^{1}$ Підласа, І. А. (2001). Розвиток концепції життєвого шляху особистості. Психологія: Збірник наукових праць Національного педагогічного університету, 13, 96; Павленко, О. В. (2019). Досвід як чинник становлення життєвої перспективи особистості: дисертація на здобуття наукового ступеню кандидату психологічних наук. Київ: Інститут психології імені Г. С. Костюка НАПН України <http://psychology-naes-ua.institute/files/pdf/ pavlenko_dissertaciya_pechat_1574025601.pdf> (2021, січень, 26).

${ }^{2}$ Путешествия и фото (2020). Что такое жизненный путь и как определить приоритеты в жизни? $<$ https://cutt.ly/nkXmM3Z> (2021, січень, 26).

${ }^{3}$ Кофман, Б. Я. (2019). Муніципальні права людини (особистості) як фактор вдосконалення конституційноправового статусу людини і громадянина. Часопис Київського університету права, 2, 65-66.

${ }^{4}$ Рубинштейн, С. Л. (2002). Основы общей психологии. СПб: Питер, 746-748.
} 
Отже, час життя - це життя людини як біологічного організму (період від появи на світ до смерті). У цьому контексті не розглядається суть, зміст життя ${ }^{1}$. Але і біологічне буття людини здійснюється в локальному соціумі за наявності всіх елементів самоорганізації, самодіяльності, самозбереження тощо. Тому, ТГ як соціальна спільнота і МСВ як сфера буття і правовий режим $€$ обов'язковими умовами для існування людини як біологічної істоти.

Життєвий цикл - це окремі, повторювані інтервали розвитку. Вже зазначалось, що прийнято виділяти такі цикли: біологічні (онтогенез), соціальні (соціалізація, адаптація), біосоціальні (зміна соціальних ролей разом з етапами дорослішання, тобто зміна поколінь). Окремо виділяють цикли сімейного, трудового життя ${ }^{2}$. Системний аналіз співвідношення наведених циклів та МСВ свідчить про їх генетичну єдність на неможливість існування один без одного, що робить сферу МСВ єдиною природною сферою реалізації життєвих циклів людини.

Під життєвим шляхом розуміють прогрес, розвиток окремої особистості ${ }^{3}$. Вважаємо, що цей термін несе в собі все ж більш високий підсумковий результативний потенціал та оцінює життєвий шлях конкретної людини по іï кінцевих результатах. Тому він може використовуватись лише у гіпотетичному розумінні та у науково-доктринальному сенсі. Але і при такому підході нам треба акцентувати увагу на суб'єктах, об'єктах, інститутах та соціальних станах, що забезпечували реалізацію такого життєвого шляху людини.

Отже, відмінність циклу від шляху міститься в тому, що в першому випадку послідовність стадій, мета, суть циклу заздалегідь строго визначена (є передначертаною і типізованою для кожної людини. - Авт.). Життєвий шлях особистості, своєю чергою, має масу варіантів, сценаріїв, розвилок і залежить від самої людини (тобто він не може бути передначертаним, передбаченим, спланованим, в силу невідомих обставин суб' єктивного і об'єктивного характеру, що супроводжують життя конкретної людини; але він також може бути ідентифікованим відповідно до його суб'єктнооб’єктному визначенню, інституційному і становому забезпеченню, - тобто, з визначенням стратегічної ролі ТГ, МСВ, стану повсякденності. - Авт.)

Разом $з$ тим, необхідно враховувати, що єдине, в чому схожі життєві шляхи різних людей, - це сенситивні (критичні) періоди, в які людина стає більш вразливою для впливу соціальних, біологічних факторів. Отже, це поворотні пункти, яким передують серйозні соціальні зміни, наприклад, вступ до школи, одруження, призив у збройні сили держави. Такі періоди називають віковими, нормативними кризами. Психічна перебудова, яка відбувається в цей момент, відіграє важливу роль ${ }^{4}$. Отже, мова тут може йти про екстраординарні події в житті людини, що напряму впливають на іiі існування та функціонування в межах ТГ і в умовах МСB - з одного боку, людина набуває суттєвої нової рольової позиції в локальному соціумі (школяр, студент, член нової родини тощо), а з іншого - нова рольова позиція може сприяти виведенню людини за межі однієї ТГ та їі входження в якості члена до іншої ТГ (служба у відповідній військовій частині за межами постійного місця проживання, зміна місця проживання з виїздом до іншого населеного пункту тощо). Разом 3 тим, у останньому випадку така людина продовжує свій життєвий шлях та життєвий цикл в межах іншої ТГ. Вважаємо, що тут мова може йти про універсальні міжособистісні зв'язки людини в межах відповідної ТГ, а також індивідуальні зв' язки людини з відповідною ТГ, що в залежності від життєвих обставин можуть змінюватись та знов «виникати», «відроджуватись» за рахунок нових системних зв'язків в межах «нової» ТГ.

4. Людина в сфері прояву своїх потреб і інтересів.

- наведена позиція напряму є пов'язаною з позиціонуванням людини в межах громадянського суспільства. Тут треба розуміти, що інтерес виступає основоположним фактором, методом і засобом інституціоналізації та конституювання громадянського суспільства, бо саме завдяки ньому фізичні особи-члени такого суспільства продукують розмаїття інтересів, відповідно до своїх потреб, які втілюються через діяльність його інституцій в суспільне життя, в нашому випадку, в життя ТГ. При цьому, на слушну думку М.П. Орзіх, громадянське суспільство, дійсно мислиме як асоціація людей, що протистоїть державі, їх соціальний будинок, який не відрізняється від суспільства, для якого

\footnotetext{
${ }^{1}$ Путешествия и фото (2020). Что такое жизненный путь и как определить приоритеты в жизни? $<$ https://cutt.ly/nkXmM3Z> (2021, січень, 26).

${ }^{2}$ там само.

3 Там само.

${ }^{4}$ Путешествия и фото (2020). Что такое жизненный путь и как определить приоритетьл в жизни? $<$ https://cutt.ly/nkXmM3Z> (2021, січень, 26).
} 
держава - конституйована суспільством публічно-правова форма політичної влади і управління, що має власний інтерес, що співвідноситься з інтересом публічної (неполітичною) влади і самоврядування ${ }^{1}$. Отже, саме в таких умовах одночасно продукуються, формуються, проявляються та реалізуються індивідуальні, групові і колективні інтереси людей, що існують і функціонують в єдиному локальному соціумі в умовах $\mathrm{MCB}$ - такий процес стає єдиним процесом формування та функціонування публічної самоврядної (муніципальної) влади, що формується на рівні МСВ та діє від імені та в інтересах жителів-членів ТГ';

- позиція людини в сфері прояву своїх потреб і інтересів актуалізує важливу проблематику інтересу в системі МСВ. Тут, на нашу думку, вельми важливою виступає методологічно вивірена доктринальна позиція М.О. Баймуратова, який виходячи з позиції К. Маркса, що інтерес «зціплює» членів громадянського суспільства ${ }^{3}$, так як воно, своєю чергою, $є$ сукупністю матеріальних життєвих відносин ${ }^{4}$, а також продуктивного висновку В.Ф. Сіренка, що «громадянське суспільство - це царство інтересів» і що «інтерес - мова громадянського суспільства» ${ }^{5}$, запропонував визначати в системі МСВ три рівня інтересів:

- інтереси самого МСB;

- інтереси території, на якій існує і функціонує ТГ; такої ТГ' .

- інтереси самої ТГ як локальної територіальної людської спільноти та інтереси жителя-члена

Вважаємо, що такий підхід, по-перше, підкреслює прямий зв'язок та детермінує взаємозв'язок між потребами людини-члена ТГ, насамперед езистенційними, i iii інтересами, а до того інтенціями, устремліннями, атитюдами тощо (як етапами формування, розвитку i прояву індивідуального, індивідуально-групового, індивідуально-колективного інтересу. - Авт.); по-друге, позиціонує індивідуальні інтереси людини-члена ТГ як складову частину «мотрійки інтересів», що виникають в системі МСВ; по-третє, робить індивідуальні інтереси людини-члена ТГ обов'язковим та визначальним елементом системи інтересів, що виникають в системі МСВ; по-четверте, демонструє особливе значення індивідуальних інтересів людини-члена ТГ, як «запускаючого» механізму всієї системи інтересів в МСВ. Наведені положення підкреслюють реальність аксіологічно і технологічно важливого доктринального висновку М.О. Баймуратова про те, що МСВ $\epsilon$ оптимальним засобом i, одночасно, домінуючою територіальною ареною задоволення сутнісних індивідуальних і групових потреб суб'єкта, за допомогою якого він самостверджується i самореалізується в громадянському суспільстві ${ }^{7}$.

5. Людина в сфері соиіалізаиії, в тому числі і правової соціалізації.

- наведена позиція людини в сфері МСВ пов'язана зі складною феноменологією ії соціалізації, в тому числі соціалізацією правовою, що виступає одним з видів загальної соціалізації. Визначаючи соціалізацію, по-перше, як комплексний процес та результат засвоєння й активного відтворення людиною соціально-культурного досвіду (знань, цінностей, норм, моралі, традицій тощо) на основі іiі діяльності, спілкування і відносин, а, по-друге, як обов'язковий фактор розвитку особистості ${ }^{8}$, представники соціологічної науки акцентують увагу на цьому феномені як такому, що позначає: а) невід'ємний процес формування, розвитку, вдосконалення і акультурації особистості; б) як один з основоположних соціальних процесів, що забезпечує повноправне існування і функціонування людини в середині локального суспільства; в) як найважливішу сторону двостороннього процесу отримання від локального соціуму відповідної профільної інформації (знань, цінностей, норм, моралі, традицій тощо) та повернення вже збагаченої інформації, що пройшла скрізь особистість людини, -

\footnotetext{
${ }^{1}$ Орзих, М. Ф. (2015). Интерес в системе местного самоуправления. Одеса: Юридична література, 236.

${ }^{2}$ Баймуратов, М. О., Григорьев, В. А. (2003). Муниципальная власть: актуальные проблемы становления и развития в Украине. Одеса: Юридическая литература, 45.

${ }^{3}$ Маркс, К., Энгельс, Ф. (1929). Святой семейство, или критика критической критики. Против Бруно Бауэра и компании, 2, 134.

${ }^{4}$ Маркс, К. (1929). К критике политической экономии, 13, 6.

${ }^{5}$ Сиренко, В. Ф. (1991). Интересы - власть - управление. Київ: Наукова думка, 6.

${ }^{6}$ Баймуратов, М. А. (1996). Международное сотрудничество органов местного самоуправления Украины: дисертація на здобуття наукового ступеню доктора юридичних наук, Одеса: Одеській державний університет ім. І. Мечнікова, 30.

7 Там само, 28.

${ }^{8}$ Вікіпедія. Вільна енциклопедія (2021). Соціалізація <https://uk.wikipedia.org/wiki/Соціалізація> (2021, січень, 26). 
назад до соціуму в контекстуалізації побудови, існування, функціонування, розвитку та вдосконалення системи комунікативної взаємодії; г) як процесу, що характеризується дихотомічністю, бо поєднує в процесі соціалізації особи функціонально-діяльнісні настанови адаптації (до колективного існування) та обособлення (у вигляді індивідуального існування), тобто збереження суб'єктності людини в умовах певного суспільства.

В такому ж напрямку здійснюється правова соціалізація людини, але тільки з застосуванням правового інструментарію, обов'язковим елементом якого виступають нормування, нормативізація, нормопроєктування та нормотворчість локального життя людини в межах $\mathrm{T}^{1}$ та в умовах МСВ. Ці складні процеси володіють відповідним організаційним, управлінським і екзистенційним потенціалом ${ }^{2}$, бо спираються на непорушний i перманентний фактологічний процес реалізації людиною на рівні МСВ свого конституційно-правового статусу. Але така реалізація стає можливою тільки за умови проходження загальної і правової соціалізації в межах територіальної людської спільноти та за допомогою її інституційної структури та членів-жителів ТГ.

6. Людина в сфері прояву свойх прав, свобод і виконання обов 'язків.

Наведена позиція є доволі складною як в контексті свого розуміння, так і в процесі своєї реалізації, бо тут об’єднується низка проблем різної властивості: з одного боку - екзистенційні прояви конкретної людини-члена ТГ, що характеризуються індивідуальністю та суто суб'єктивною властивістю, а з іншого - об' єктивні умови функціонування територіальної людської спільноти в процесі повсякденного існування, що обмежене наявними ресурсами, які, своєю чергою, споживаються колективно.

Вважаємо за потрібне наголосити на тому, що в цьому процесі основоположним, «опорним»

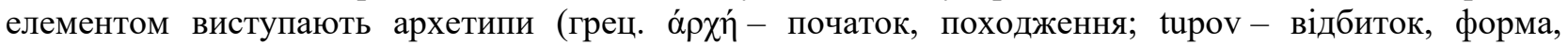
зразок) - у широкому розумінні - наскрізні символічні структури культури, що асоціюють певний тематичний матеріал свідомого та підсвідомого функціонування людських цінностей ${ }^{3}$.

Отже, найбільш глибоке розуміння архетипам надається у психології- під шаром «особистісного несвідомого», що складали основний предмет вивчення в класичному психоаналізі 3. Фройда, К. Юнг виявляє «колективне несвідоме», що трактується як загальнолюдська основа («грибниця») душевного життя індивідів, наслідувана, а не сформована на базі індивідуального досвіду. Якщо в особистісному несвідомому основну роль грають «комплекси» (наприклад, комплекс Едипа, комплекс неповноцінності), то структуроутворюючими елементами колективного несвідомого є «архетип»- універсальні моделі несвідомої психічної активності, котрі спонтанно визначають людське мислення і поведінку. Архетипи можна порівняти з «апріорними формами» пізнання I. Канта, однак вони позбавлені їх абстрактності й емоційно насичені. Власне архетипи не мають конкретного психічного змісту (К. Юнг уподібнював їх осям кристала); інша справа архетипічні уявлення (символи) як результат спільної роботи свідомості і колективного несвідомого. Символи це єдність прозорої свідомості образа і таємного і неексплікованого змісту що стоїть за ним, що веде в несвідомі глибини психіки ${ }^{4}$.

Звідси, архетипи в поведінці людей на локальному рівні функціонування соціуму проявляються:

а) у вигляді їх життевого досвіду,

б) що набувається в процесі життєдіяльності в територіальній людській спільноті,

в) завдяки інтенсивному використанню відповідних життєвих форм та їх наступної типізації,

г) що передаються від одного покоління (попереднього, старшого) іншому поколінню людей (наступному, молодшому),

д) вагомим аргументом на користь праксеологічної системи «архетипи -права (свободи, обов'язки) людини /особистості/)» виступає те, що на рівні МСВ в межах ТГ виникає, формується,

\footnotetext{
${ }^{1}$ Чорнолуцький, Р. В. (2016). Нормотворчість органів місцевого самоврядування: телеологічні домінанти, що базуються на екзистенційних інтересах територіальної громади. Науковий вісник публічного та приватного права: збірник наукових пращь. Київ, 5, 51-52.

2 Чорнолуцький, Р. (2017). Нормопроектування в конституційному праві України: парадигма процесуальностадійного забезпечення актуальних питань. Evropsky politicky a pravni diskurz, 4, 2, 54-55.

${ }^{3}$ Енциклопедія сучасної України (2021). Архетипи $<\mathrm{http}: / /$ esu.com.ua/search_articles.php?id=44787> (2021, січень, 26).

${ }^{4}$ Вікіпедія. Вільна енциклопедія (2021). Архетип (за К. Г. Юнгом)

$<$ https://uk.wikipedia.org/wiki/Архетип_(за_К._Г._Юнгом) > (2021, січень, 26).
} 
розвивається, реалізується системний комплекс конституційних прав, свобод, обов'язків людини (особистості).

Виходячи з того, що права людини, іiі свободи, виконання нею обов'язків виступають

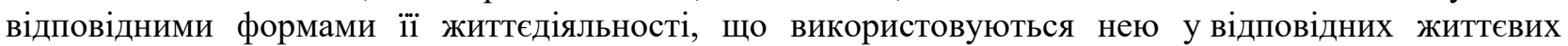
обставинах - архетипічні прояви таких форм:

a) складають загальний досвід всієї людської цивілізації, включаючи кожну ТГ;

б) такий досвід постійно і регулярно використовується ії членами-жителями; а також

в) ними розвивається, вдосконалюється та передається наступним поколінням;

г) сприяє формуванню нових життєвих форм в межах ТГ в умовах МСВ як прообразів нових прав людини (особистості).

Отже, колективне існування людини в межах ТГ дає змогу набути відповідний життєвий досвід, який проявляється у пізнанні феноменології прав, свобод і обов'язків людини, що реалізуються нею у своєму повсякденному житті.

7. Людина в сфері прояву публічної влади на локальному рівні соиіуму.

Наведена позиція демонструє складні проблеми взаємозв'язку і взаємозалежності публічної самоврядної (муніципальної) влади та громадянського суспільства, а саме:

- визначаючи складний і суперечливий характер наведеної проблематики, М.О. Баймуратов слушно зазначає, що: а) питання існування системи публічної влади сьогодні - це питання про можливість перебудови, причому корінної і принципової, котра знаходить своє рішення, насамперед, у вирішенні проблеми зміни пріоритетів; б) це означає відмову від ідеї тоталітарної державності «людина для держави» на користь принципу державності демократичної - «держава для людини»; в) тільки в такому випадку держава, публічна влада почне прислуховуватися до процесів, що відбуваються в суспільстві, поставить своєю основною задачею створення сприятливих умов для самопізнання, саморозвитку особистості, реалізації ії численних запитів і потреб ${ }^{1}$. Отже, мова, насамперед, йде про зміну всієї філософії влади у посттоталітарній державі, як такої; а також, про висунення людини, ії потреб і інтересів у центр державного буття (див. ст. 3 Конституції України ${ }^{2}$;

- особливу увагу в цьому процесі треба звернути на його темпоральні рамки, - на слушну думку О. М. Ариніна, «така влада повинна боятися спізнитися, відстати у своєму розвитку від особистостей i використовувати енергію особистостей, насамперед найяскравіших, найвільніших i найпередовіших, тому що їхня енергія надихає всіх інших»³;

- виходячи саме з настанов взаємодії та взаємовпливу публічної влади і людини, представниками муніципально-правової доктрини, зокрема М.О. Баймуратовим і В.А. Григор'євим, висунута продуктивна ідея формування публічної самоврядної (муніципальної) влади [18], що формується на рівні МСВ, діє від імені ТГ та в її інтересах;

- отже, можна констатувати, що людина, виступаючи членом ТГ, саме в умовах МСВ в рамках публічної самоврядної (муніципальної) влади, за допомогою органів такої влади - органів місцевого самоврядування, що сформовано самою ТГ (представницькі органи ТГ) або за їі активною допомогою (виконавчі органи ТГ), колективно, - може реалізувати свої екзистенційні настанови.

Висновки. Резюмуючи викладене вище, можна дійти наступних висновків:

-в основі проблематики існування і функціонування людини в умовах МСВ в межах ТГ, що завжди представляла собою вельми складний та суперечливий фактор соціального буття людини лежать відповідні екзистенційні настанови іiї індивідуального існування в локальній територіальній спільноті, що пов'язані з тим, що: а) саме в рамках ТГ людина здійснює свій життєвий цикл, починаючи його від свого народження, і закінчуючи іiі смертю (екзистениійно-темпоральна настанова. - Авт.); б) такий життєвий цикл переважно здійснюється в умовах повсякденності філософського стану коли людина формує і використовує типізовані форми життєдіяльності недарма повсякденність розуміли як сферу рутинних, звичних, одноманітно повторюваних 3 дня удень малих дій i вчинків, зрозумілих і доступних, виконуваних майже автоматично, без спеціального напруження свідомості і рефлексії (повсякденно-ординарна настанова. - Aвт.); в) в ТГ людина продукує свої екзистенційні інтенції, устремління, потреби, інтереси, атитюди, які потім

\footnotetext{
${ }^{1}$ Баймуратов, М. О. (2003). Публічна самоврядна (муніципальна) влада та громадянське суспільство: проблеми взаємозв'язку і взаємозалежності. Актуальні проблеми держави і права, 21, 131-138.

$<$ http://nbuv.gov.ua/UJRN/apdp_2003_21_26> (2021, січень, 26).

${ }^{2}$ Конституичія Украӥни, 1996 (Верховна Рада України). Відомості Верховної Ради України, $30,141$.

${ }^{3}$ Аринин, А. Н. (2000). Государство для человека. Общественные науки и современность, 6, 48.
} 
реалізуються в ії межах (мотиваційно-стимулююча ознака. - Авт.); г) всі наведені екзистенційні настанови реалізуються людиною через систему комунікативної взаємодії з іншими членами ТГ у вигляді відповідних прав і свобод (комунікативна настанова. - Авт.); г') в умовах МСВ в межах ТГ людина індивідуально, або в складі групи, або колективно потребляє суспільні блага різної властивості (матеріальні, економічні, політичні, духовні тощо) та користується відповідними послугами, що їй надає ТГ через відповідну діяльність ОМСВ, які створюють відповідну структуру місцевого господарства (локально-циивілізаиійна настанова. - Авт.);

- для більш глибокого дослідження проблематики існування і функціонування людини в умовах MCB в межах ТГ вважаємо за потрібне побудувати відповідну систему координат «людина - МСВ», що базується на основоположних, індикативних ознаках, які в своєму розвитку демонструють параметральні межі профільної системи, а саме дають можливість визначити та виокремити наступні позиції: а) людина як індивідуум в рамках локальної спільноти та в умовах самоорганізації (в межах МСВ); б) людина як центральна фігура-суб'єкт МСВ (людиноцентризм в МСВ); в) людина в МСВ як в сфері реалізації свого життєвого циклу; г) людина в сфері прояву своїх потреб і інтересів; г') людина в сфері соціалізації, в тому числі і правової соціалізації; д) людина в сфері прояву своїх прав, свобод і виконання обов'язків; е) людина в сфері прояву публічної влади на локальному рівні соціуму;

- наведені вище позиції (ознаки) знаходяться одна зодною усистемно-комплексному логічному екзистенційно-діяльнісному взаємному зв'язку, так як $\epsilon$ пов'язаними через просторові (соціальний простір) та міжособистісні (комунікативна взаємодія) зв'язки, засади, концепти та соціально-індивідуальні, соціально-групові і соціально-колективні настанови, телеологічні домінанти та практичні результати функціонування людини в МСB;

- системний аналіз наведених вище позицій (ознак) переконливо доказує переваги колективного існування людини в межах ТГ з метою реалізації своїх екзистенційних потреб і інтересів.

\section{References:}

1. Kolyastruk, O. (2009). Ponyattya povsyakdennosti v suchasniy naukoviy humanitarystytsi. Ukrayina XX st.: kultura, ideolohiya, polityka [The concept of everyday life in the modern scientific humanities. Ukraine of the XX century: culture, ideology, politics], 15, 46-56. <http://resource.history.org.ua/publ/xxx_2009_15_1_46> (2021, January, 26). [in Ukrainian].

2. Orzikh, M. F. (2015). Opyt vvedeniya v konstitutsionnoye pravo Ukrainy. Odesa: Yuridichna líteratura, 315-326. [in Ukrainian].

3. Kofman, B. YA. (2019). Munitsypalni prava lyudyny (osobystosti) yak faktor vdoskonalennya konstytutsiynopravovoho statusu lyudyny i hromadyanyna [Municipal human rights (personality) as a factor in improving the constitutional and legal status of man and citizen]. Chasopys Kyyivskoho universytetu prava [Journal of Kyiv University of Law], 2, 64-71. [in Ukrainian].

4. Wikipedia. The Free Encyclopedia (2021). Intersubyektivnost [Intersubjectivity] $<$ https://ru.wikipedia.org/wiki/Интерсубъективность> (2021, January, 26). [in Russian].

5. New Philosophical Encyclopedia (2021). Intersubyektivnost [Intersubjectivity] $<$ https://iphlib.ru/library/collection/ newphilenc/document/HASH44342313953cffcc43a844> (2021, January, 26). [in Russian].

6. Orzikh, M. F. (2015). Konstitutsiya - sistemoobrazuyushchaya osnova prava Ukrainy: prikladnyye problemy [The Constitution is the backbone of the law of Ukraine: applied problems]. Odessa: Yuridichna literatura, 345-346. [in Russian].

7. Haliakhmetov, I. A. (2016). Munitsypalne pravo Ukrayiny: metodolohiya stanovlennya ta rozvytku [Municipal law of Ukraine: methodology of formation and development]. Kyiv: KNEU. [in Ukrainian].

8. Kofman, B. Ya. (2020). Rol mizhnarodnykh pravovykh standartiv prav lyudyny u formuvanni pravovoho statusu lyudyny i hromadyanyna [The role of international legal standards of human rights in the formation of the legal status of man and citizen]. Chasopys Kyivskoho universytetu prava [Journal of Kyiv University of Law], 1, 109-114. [in Ukrainian].

9. Golos Ukrainy (2017) [Voice of Ukraine (2017)]. Chelovekotsentrizm: kontekst nauchnykh realiy [Human-centrism: the context of scientific realities] <http://www.golos.com.ua/rus/article/289180> (2021, January, 26). [in Russian].

10. Rekomendatsiyi Konhresu mistsevykh i rehionalnykh vlad Yevropy 280 (2010) pro rol mistsevykh i rehionalnykh orhaniv vlady $v$ dotrymanni prav lyudyny, 2011 (Rada Yevropy) [Recommendations of the Congress of Local and Regional Authorities of Europe 280 (2010) on the role of local and regional authorities in the observance of human rights, 2011 (Council of Europe)]. Council of Europe <https://rm.coe.int/168071b6bc> (2021, January, 26). [in Ukrainian].

11. Batanov, O. V. (2017). Lyudynotsentryzm u munitsypalnomu pravi: teoretychni ta prykladni aspekty [Anthropocentrism in municipal law: theoretical and applied aspects]. Almanakh prava [Almanac of Law], 8, 69-73. [in Ukrainian]. 
12. Puteshestviya i foto (2020) [Travel and photography (2020)]. Chto takoye zhiznennyy put $i$ kak opredelit prioritety $v$ zhizni? [What is a life path and how to prioritize life?] $<$ https://cutt.ly/nkXmM3Z> (2021, January, 26). [in Russian].

13. Maksymenko, S. D. (2021). Zahalna psykholohiya [General Psychology]. Westudents.com.ua $<$ https://westudents.com.ua/glavy/76983-jittviy-shlyah-lyudini. html> (2021, January, 26). [in Ukrainian].

14. Pidlasa, I. A. (2001). Rozvytok kontseptsiyi zhyttyevoho shlyakhu osobystosti [Development of the concept of a person's life path]. Psykholohiya: Zbirnyk naukovykh prats Natsionalnoho pedahohichnoho universytetu [Psychology: Collection of scientific works of the National Pedagogical University],13, 95-102. [in Ukrainian].

15. Pavlenko, O. V. (2019). Dosvid yak chynnyk stanovlennya zhyttyevoyi perspektyvy osobystosti [Experience as a factor in the formation of life prospects of the individual]: dysertatsiya na zdobuttya naukovoho stupenyu kandydatu psykholohichnykh nauk [the dissertation for the degree of candidate of psychological sciences]. Kyiv: G. S. Kostyuk Institute of Psychology, National Academy of Pedagogical Sciences of Ukraine $<$ http://psychologynaes-ua.institute/files/pdf/pavlenko_dissertaciya_pechat_1574025601.pdf> (2021, January, 26). [in Ukrainian].

16. Rubinshteyn, S. L. (2002). Osnovy obshchey psikhologii [Fundamentals of General Psychology]. SPb: Piter. [in Russian].

17. Orzykh, M. F. (2015). Interes v systeme mestnoho samoupravlenyya [Interest in the system of local self-government]. Odesa: Yurydychna literatura, 236-242. [in Russian].

18. Baymuratov, M. O., Grigoryev, V. A. (2003). Munitsipalnaya vlast: aktualnyye problemy stanovleniya $i$ razvitiya v Ukraine [Municipal Power: Actual Problems of Formation and Development in Ukraine]. Odesa: Yuridicheskaya literatura. [in Russian].

19. Marx, K., Engels, F. (1929). Svyatoy semeystvo, ili kritika kriticheskoy kritiki. Protiv Bruno Bauera i kompanii [Holy family, or criticism of critical criticism. Against Bruno Bauer and company], 2, 3-230. [in Russian].

20. Marx, K. (1929). K kritike politicheskoy ekonomii [To the criticism of political economy], 13, 1-167. [in Russian].

21. Sirenko, V.F. (1991). Interesy - vlast-upravleniye [Interests - power - management]. Kiev: Naukova Dumka. [in Russian].

22. Baymuratov, M. A. (1996). Mezhdunarodnoe sotrudnychestvo orhanov mestnoho samoupravlenyya Ukrayny [International cooperation of local governments of Ukraine]: dysertatsiya na zdobuttya naukovoho stupenyu doktora yurydychnykh nauk [the dissertation for the degree of Doctor of Laws]. Odesa: I. Mechnikov Odesa State University. [in Russian].

23. Wikipedia. Free Encyclopedia (2021). Sotsializatsiya [Socialization] <https://uk.wikipedia.org/wiki/Cоціалізація> (2021, January, 26). [in Ukrainian].

24. Chornolutsky, R. V. (2016). Normotvorchist orhaniv mistsevoho samovryaduvannya: teleolohichni dominanty, shcho bazuyutsya na ekzystentsiynykh interesakh terytorialnoyi hromady [Rule-making of local self-government bodies: teleological dominants based on the existential interests of the territorial community]. Naukovyy visnyk publichnoho ta pryvatnoho prava: zbirnyk naukovykh prats [Scientific Bulletin of Public and Private Law: a collection of scientific papers]. Kyiv, 5, 46-52. [in Ukrainian].

25. Chornolutsky, R. (2017). Normoproektuvannya v konstytutsiynomu pravi Ukrayiny: paradyhma protsesualnostadiynoho zabezpechennya aktualnykh pytan [Norm-designing in the constitutional law of Ukraine: a paradigm of procedural-stage maintenance of actual questions]. Evropsky politicky a pravni diskurz [European political and legal discourse], 4, 2, 54-60. [in Ukrainian].

26. Encyclopedia of modern Ukraine (2021). Arkhetypy [Archetypes] $<$ http://esu.com.ua/search_articles.php?id=44787> (2021, January, 26). [in Ukrainian].

27. Wikipedia. Free Encyclopedia (2021). Arkhetip (za K. G. Yungom) [Archetype (by C.G. Jung)] $<$ https://uk.wikipedia.org/wiki/Архетип_(за_К._Г._Юнгом) > (2021, January, 26). [in Ukrainian].

28. Baymuratov, M. O. (2003). Publichna samovryadna (munitsypalna) vlada ta hromadyanske suspilstvo: problemy vzayemozvyazku i vzayemozalezhnosti [Public self-government (municipal) government and civil society: problems of interconnection and interdependence]. Aktualni problemy derzhavy i prava [Current issues of state and law], 21, 131-138.<http://nbuv.gov.ua/UJRN/apdp_2003_21_26> (2021, January, 26). [in Ukrainian].

29. Konstytutsiya Ukrayiny, 1996 (Verkhovna Rada Ukrayiny) [Constitution of Ukraine, 1996 (Verkhovna Rada of Ukraine)]. Vidomosti Verkhovnoyi Rady Ukrayiny [Information of the Verkhovna Rada of Ukraine], $30,141$. [in Ukrainian].

30. Arinin, A. N. (2000). Gosudarstvo dlya cheloveka [State for a person]. Obshchestvennyye nauki i sovremennost [Social sciences and modernity], 6, 48-61. [in Russian]. 